\title{
Rootstock-Dependent Response of Hass Avocado to Salt Stress
}

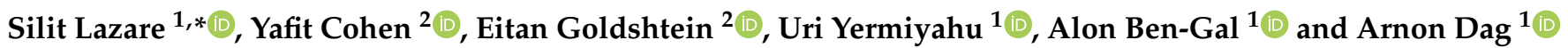 \\ 1 Gilat Research Center, Agricultural Research Organization, Volcani Institute, M.P. Negev, Gilat 8528000, Israel; \\ uri4@volcani.agri.gov.il (U.Y.); bengal@volcani.agri.gov.il (A.B.-G.); arnondag@volcani.agri.gov.il (A.D.) \\ 2 Institute of Agricultural Engineering, Agricultural Research Organization, Volcani Institute, \\ Rishon LeZion 7505101, Israel; yafitush@volcani.agri.gov.il (Y.C.); eitan@volcani.agri.gov.il (E.G.) \\ * Correspondence: silit1@volcani.agri.gov.il; Tel.: +972-8-992-8647
}

check for

updates

Citation: Lazare, S.; Cohen, Y.; Goldshtein, E.; Yermiyahu, U.;

Ben-Gal, A.; Dag, A.

Rootstock-Dependent Response of Hass Avocado to Salt Stress. Plants 2021, 10, 1672. https://doi.org/ $10.3390 /$ plants 10081672

Academic Editors:

Ewa Hanus-Fajerska and

Iwona Kamińska

Received: 29 July 2021

Accepted: 11 August 2021

Published: 13 August 2021

Publisher's Note: MDPI stays neutral with regard to jurisdictional claims in published maps and institutional affiliations.

Copyright: (C) 2021 by the authors Licensee MDPI, Basel, Switzerland. This article is an open access article distributed under the terms and conditions of the Creative Commons Attribution (CC BY) license (https:// creativecommons.org/licenses/by/ $4.0 /)$.

\begin{abstract}
Salt stress is a major limiting factor in avocado (Persea americana) cultivation, exacerbated by global trends towards scarcity of high-quality water for irrigation. Israeli avocado orchards have been irrigated with relatively high-salinity recycled municipal wastewater for over three decades, over which time rootstocks were selected for salt-tolerance. This study's objective was to evaluate the physiological salt response of avocado as a function of the rootstock. We irrigated fruit-bearing 'Hass' trees grafted on 20 different local and introduced rootstocks with water high in salts (electrical conductivity of 1.4-1.5 dS/m). The selected rootstocks represent a wide range of genetic backgrounds, propagation methods, and horticultural characteristics. We investigated tree physiology and development during two years of salt exposure by measuring $\mathrm{Cl}$ and $\mathrm{Na}$ leaf concentrations, leaf osmolality, visible damages, trunk circumference, $\mathrm{LAI}, \mathrm{CO}_{2}$ assimilation, stomatal conductance, spectral reflectance, stem water potential, trichomes density, and yield. We found a significant effect of the rootstocks on stress indicators, vegetative and reproductive development, leaf morphogenesis and photosynthesis rates. The most salt-sensitive rootstocks were VC 840, Dusa, and VC 802, while the least sensitive were VC 159, VC 140, and VC 152. We conclude that the rootstock strongly influences avocado tree response to salinity exposure in terms of physiology, anatomy, and development.
\end{abstract}

Keywords: crop trees; $\mathrm{NaCl}$; remote sensing; salt susceptibility; trichomes

\section{Introduction}

Commercial modern fruit orchards are typically composed of trees with scions grafted on to rootstocks of different genetic origins. Grafting is a major element of propagation processes and rootstock selection is a key component in successful and healthy orchard establishment [1]. Rootstock selection can be based on adaptability to soil characteristics, pest and/or disease pressure, and desired root-scion propagation and growth interactions. Avocado (Persea americana) is a crop of rising importance, with high nutritional and economic values [2]. The expansion of avocado cultivation areas might be challenging due to the crop's susceptibility to stress brought upon by weather, irrigation water quality, and soil conditions including temperature, acidity, oxygen availability, and salinity [3-6]. The sensitivity of avocado to such conditions highlights that trees must be conditioned and adjusted to their specific local environment. The complexity in advancing its production increases when considering that avocado consumers generally prefer a specific variety ('Hass') [7]. Rootstocks must therefore be matched to cultivation conditions and rootstock-scion relationships and subsequent crop performance should be evaluated. Rootstocks have long been used to help sensitive species cope with biotic and abiotic stresses. With avocado, most research has focused on diseases such as phytophthora root rot [8], botryosphaeria branch dieback [9], and verticillium wilt [10]. Abiotic stresses addressed in rootstock studies include drought [11], calcareous soil [12], and salinity [13].

Salt susceptibility in agricultural crops is defined by a reduction in plant growth, development, and productivity [14]. Avocado is considered one of the most salt-sensitive 
crops [15]. Its rootstocks are of three primary genetic sources: Mexican, West Indian, and Guatemalan [16]. Mexican rootstocks were found to be more susceptible to salinity than others $[17,18]$. Physiological responses of avocado to salt exposure or wastewater irrigation were investigated and reviewed during the last 15 years in a number of studies [6,19-21]. The studies focused mostly on scion photosynthesis rates, productivity, and nutritional status, revealing the negative effect of salinity exposure on these indices. In our opinion, the influence of rootstocks on avocado response to salinity is particularly engaging, and we therefore invested in data collection from many rootstocks grafted with the same (Hass) scion, in order to identify their distinct effects.

Salt stress is known to negatively affect growth and productivity through both osmotic and toxic mechanisms [22]. The osmotic damage is expressed as changes in water status, similar to that of drought, measured by reduction in stem water potential (SWP) $[23,24]$. The potential refers to the energy status of water in a plant, which reflects the balance between water status in the soil, water taken up from soil by roots, atmospheric water status and demand, and plant physiological responses, particularly stomatal resistance or closure [25]. The root's water uptake is highly influenced by exposure to salts, which may change root hydraulic characteristics and decrease their function [26,27]. Salt exposure decreases water potential and consequently inhibits a number of metabolic and physiological functions. To compensate for salinity induced stress, some plants respond through osmotic adjustment [28]. This mechanism includes an active gradual decrease in cellular water content, which leads to accumulation of solutes within the cell and water movement inside it [29]. Osmotic adjustment develops gradually under slow and uniform rates of dehydration. With this drought-acclimation mechanism, plants maintain high turgor potential under dehydration and avoid inhibition of their functions. Under drought stress, high solute concentrations may indicate tolerance, but when salt stress causes osmotic instability, high leaf osmolality might imply the opposite [30,31]. Salinity also reduces $\mathrm{CO}_{2}$ assimilation, due to stomata closure [32]. The toxic effect of salt exposure includes chlorophyll degradation due to chloride $(\mathrm{Cl})$ accumulation in the chloroplasts and leaf necrosis due to an increase in the sodium:potassium (Na:K) ratio [33-35]. These effects may also decrease the plant's photosynthetic rates and consequently its reproduction and yield.

The presented work was conducted in a fruit-bearing avocado orchard irrigated with high salinity water $\left(280-300 \mathrm{mg} \mathrm{Cl} / \mathrm{L}^{-1}\right.$, electrical conductivity (EC) $1.4-1.5 \mathrm{dS} / \mathrm{m}$ ) for two consecutive years. We used a single scion-'Hass' - grafted on 20 different rootstocks, which were previously characterized as relatively tolerant to several stresses [12]. The divergent sensitivity of the rootstocks to salt stress was evaluated by several plant stress indicators, together with vegetation and reproduction measurements. The extensive rootstock collection, with 25 repetitions each, provided a unique opportunity to study the response of mature avocado trees thoroughly and to provide consequent applicable recommendations.

\section{Materials and Methods}

\subsection{Experimental Site and Plant Material}

The research was conducted at the Gilat Research Center, Israel $\left(31^{\circ} 20^{\prime} 08.6^{\prime \prime} \mathrm{N}\right.$ $\left.34^{\circ} 39^{\prime} 57.0^{\prime \prime} \mathrm{E}\right)$. Twenty seedling and vegetatively cloned (VC) rootstocks were grafted in 2011 with 'Hass' scions and planted in 2013. The rootstocks represent a wide range of genetic backgrounds, propagation methods, and horticultural characteristics (Table 1). Each rootstock had 25 trees as repetitions, in groups of five trees each in five plots placed randomly in the orchard (Figure S1). Each plot contained, aside from the five 'Hass' trees, one 'Ettinger' tree grafted onto the same rootstock, as a pollenizer. All trees were pruned uniformly once a year, after harvest. The soil was characterized as sandy loam, with $11.5 \%$ calcium carbonate. In December 2018, prior to the exposure to salinity, soil EC and pH in saturated paste extract were $0.73 \mathrm{dS} / \mathrm{m}$ and 7.79 , respectively. Soil $\mathrm{Na}$ and $\mathrm{Cl}$ concentrations in the saturated paste extract were 22.27 and $17.62 \mathrm{mg} / \mathrm{L}$, respectively, and soil adsorption ratio (SAR) was 0.9. The orchard was drip-irrigated and fertigated according to local commercial recommendations with liquid fertilizer (Shefer ${ }^{\mathrm{TM}}+3$, Fertilizers \& Chemicals Ltd., 
Kiryat Ata, Israel) twice a week, from March to October. The fertilizer solution contained $7 \%$ nitrogen $(\mathrm{N}), 2 \% \mathrm{P}_{2} \mathrm{O}_{5}$ and $7 \% \mathrm{~K}_{2} \mathrm{O}, 300 \mathrm{mg} / \mathrm{kg}$ iron $(\mathrm{Fe}), 150 \mathrm{mg} / \mathrm{kg}$ manganese $(\mathrm{Mn})$, $75 \mathrm{mg} / \mathrm{kg}$ zinc $(\mathrm{Zn}), 11 \mathrm{mg} / \mathrm{kg}$ copper $(\mathrm{Cu})$, and $8 \mathrm{mg} / \mathrm{kg}$ molybdenum (Mo). Annual irrigation was 14,508 m3/ha, and annual liquid fertilization was $2940 \mathrm{~kg} / \mathrm{ha}$.

Table 1. Rootstocks evaluated in the experiment.

\begin{tabular}{lcc}
\hline \multicolumn{1}{c}{ Rootstock } & Origin & Propagation Method \\
\hline Degania 189 & WI & Seedling \\
Degania 62 & WI & Seedling \\
Dusa & Mex $\times$ Gu & VC \\
Nachlat 3 & WI & Seedling \\
VC 140 & WI & VC \\
VC 152 & WI & VC \\
VC 159 & WI & VC \\
VC 207 & Mex $\times$ WI & VC \\
VC 26 & WI & VC \\
VC 28 & WI & VC \\
VC 320 & WI & VC \\
VC 55 & WI & VC \\
VC 66 & WI & VC \\
VC 68 & WI & VC \\
VC 801 & WI & VC \\
VC 802 & WI & VC \\
VC 804 & WI & VC \\
VC 840 & Mex & VC \\
VC 96 & WI & VC \\
Waldin & WI & VC \\
\hline WI & WI & \\
\hline
\end{tabular}

WI-West Indian; Mex—Mexican; Gu—Guatemalan; and VC—vegetatively cloned.

In March 2019, $\mathrm{NaCl}$ was added to the fertigation solution to reach $280-300 \mathrm{mg} \mathrm{Cl} / \mathrm{L}$, with EC of 1.4-1.5 dS/m. This level of salinity is considered harmful but not lethal to avocado [36,37]. A saturated paste extract of the soil in December 2019 had an EC of $1.18 \mathrm{dS} / \mathrm{m}$ and $\mathrm{pH}$ of $7.32,70.09 \mathrm{mg} / \mathrm{L} \mathrm{Cl}, 86.82 \mathrm{mg} / \mathrm{L} \mathrm{Na}$, and a SAR of 3.81.

During May 2020, extreme weather caused severe burning damage to the edge trees of the orchard. Hence, the following tests did not include those damaged trees.

Throughout the manuscript, we use the rootstock names when referring to either roots, trunks, or leaves. However, the leaves and the upper part of the trunks are genetically identical and belong to the 'Hass' scions grafted onto the rootstocks. Using the rootstock names is for distinguishing purposes.

\subsection{Mineral Analysis, Osmolality, and Trichoms}

Diagnostic leaves (youngest fully expanded leaves) were sampled from the trees in November 2019 and 2020 . Leaves were dried at $60-70{ }^{\circ} \mathrm{C}$ for $48 \mathrm{~h}$, ground and minerals were extracted in water $(0.1 \mathrm{~g}$ dry matter in $10 \mathrm{~mL}$ deionized water). Chloride concentration in the extract was determined using an MKII chloride analyzer 926 (Sherwood) and Na concentration was determined by an atomic absorption spectrometer (Analyst 200, PerkinElmer, Waltham, MA, USA) (Figure 1). 


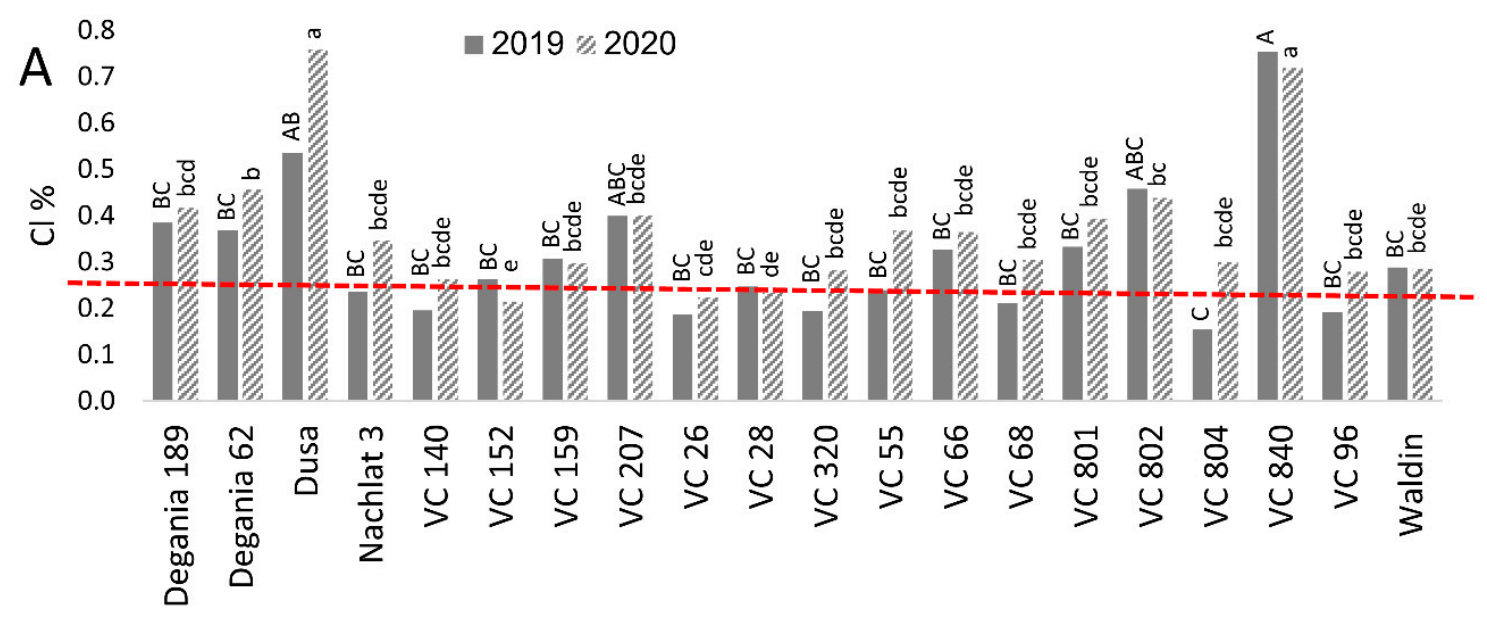

B

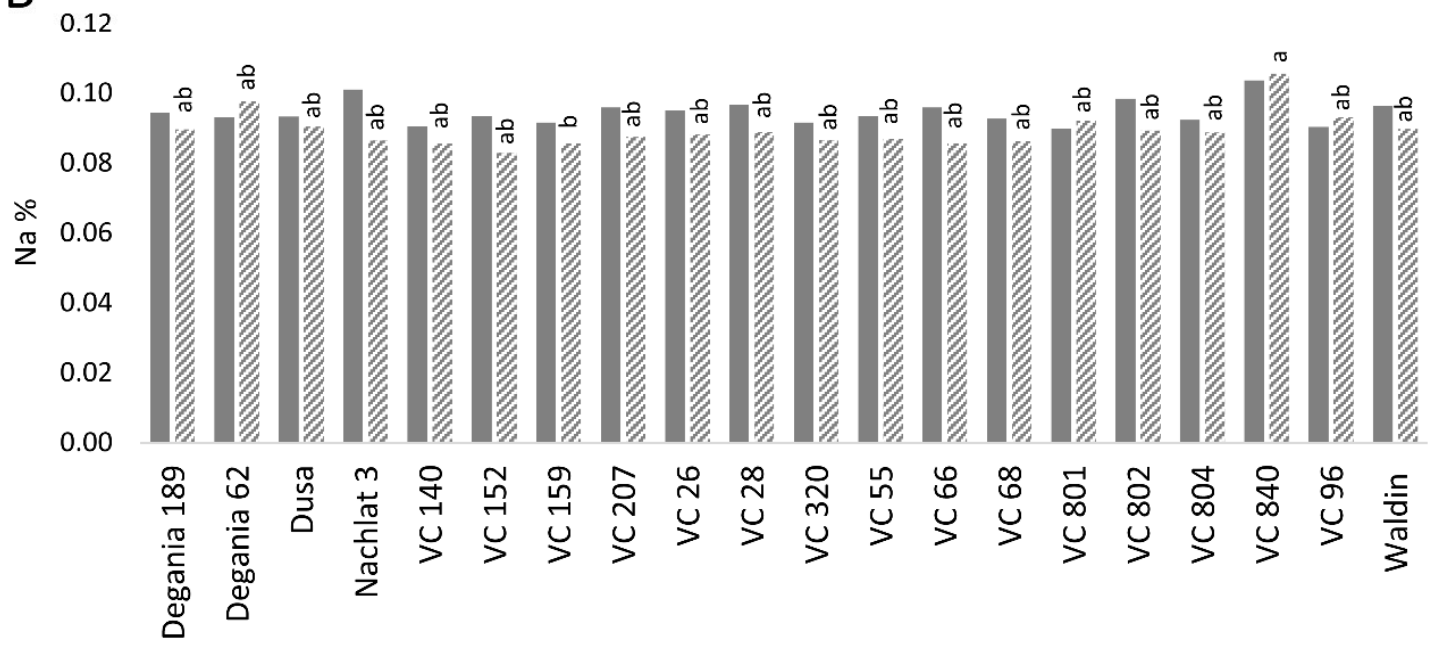

Figure 1. Salt content in leaves of 'Hass' avocado trees grafted onto various rootstocks. (A): chlorides. (B): sodium. Different letters (upper case for 2019 and lower case for 2020) represent significant $(p \leq 0.05)$ differences between rootstocks. The dashed line represents the avocado leaf $\mathrm{Cl}$ upper standard suggested by the University of California, above which is considered harmful to the trees. SD values are presented in Table S1.

Diagnostic leaves (three leaves per tree) of all rootstocks were sampled on August 2020 and frozen immediately in liquid N. Cell sap was extracted by centrifuging the thawed samples for $10 \mathrm{~min}$ at $12,000 \mathrm{rpm}$. Sap osmolality $\left(\mathrm{mol} \mathrm{kg}^{-1}\right)$ was measured using an osmometer (Vapro-5600, Wescor, South Logan, Utah, USA). Diagnostic leaves of all rootstocks were sampled (10 leaves for each rootstock) during August 2020 and observed under florescence stereoscope (Nikon SMZ25, Nikon, Tokyo, Japan). Trichomes were counted in three fixed areas of $300 \mu \mathrm{m}^{2}$ at the abaxial side of each leaf, and the images were processed with NIS Elements Br software.

\subsection{Salt Damage Visual Survey}

On April 2020, a survey was taken in the orchard, in which each tree was ranked by its visual salt damage symptoms (leaf necrosis and defoliation) from 0-3. A score of 0 meant "no symptoms", and scores of 1-3 indicated gradual severity in the symptoms (Figure 2B-E). The score was given to the general performance of the tree, regarding both the young and old leaves. 

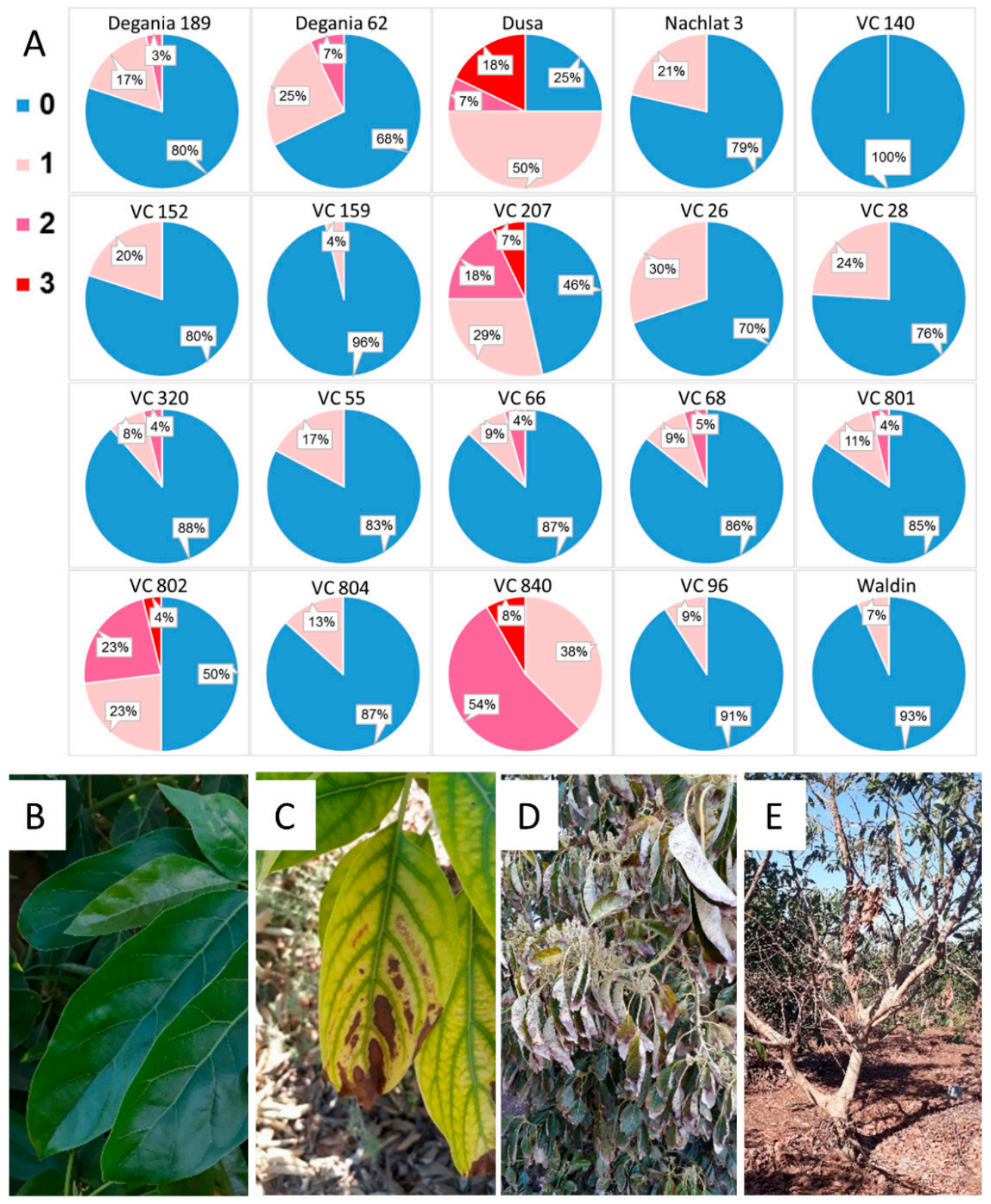

Figure 2. Salt damage in the orchard after a year of irrigation with water high in salt. (A): visual survey. (B): healthy avocado leaves. (C): leaf necrosis. (D): severe leaf burns. (E): defoliation. In the survey, blue (0) represents no visual salt damage and pink/red shades (1-3) represent salt damage in increasing severity, from light necrosis to tree defoliation.

\subsection{Vegetation Indices and Photosynthetic Parameters}

The trunks of all trees were marked $15 \mathrm{~cm}$ above the grafting location. The circumference was measured on December 2018 and then annually after harvest (December) at the mark. Leaf area index (LAI) and photosynthetic active radiation (PAR) were measured on a bright day at noon, in August 2020, by a portable ceptometer (AccuPAR LP-80).

In September 2020, 18 months after initiation of the salinity treatment, on a bright sunny day, midday $\mathrm{CO}_{2}$ assimilation, transpiration, and stomatal conductance were measured. These measurements were performed on new mature leaves by a CIRAS-3 portable photosynthesis system (PP Systems). 


\subsection{Remotely Sensed Vegetation Indices}

A drone flight was conducted with a DJI Matrice 600 pro (DJI, Shenzhen, China) equipped with a MicaSense RedEdge-MX multispectral camera (MicaSense, Seattle, WA, USA) facing nadir. The Rededge-MX has five sensors (blue: $465-485 \mathrm{~nm}$, green: $550-570 \mathrm{~nm}$, red: $663-673 \mathrm{~nm}$, red edge: $712-722 \mathrm{~nm}$, and near infrared: $820-860 \mathrm{~nm}$ ). The drone was flown at 12:00 noon to reduce the shadows of trees in the canopy. Flight path was planned and executed as a grid mission with the PIX4D capture 4.10.0(11) application (Pix4D SA; Lausanne, Switzerland) installed on an Apple IPAD. The altitude of the flight was $30 \mathrm{~m}$ above ground level, with a front and side overlap of $80 \%$, and the corresponding ground sampling distance (GSD) was $2.08 \mathrm{~cm} / \mathrm{px}$. Calibration images of the MicaSense calibrated reflectance panel were acquired before and after the flight to ensure image quality. In addition, 6 ground control points (GCP) were placed on the edges and 1 GCP placed inside the orchard. The coordinates of the GCP were measured using real-time kinematic GPS (Spectra Precision SP60 receiver, Trimble) to increase the accuracy of the image photogrammetric processing. The photogrammetric processing was carried out using the Agisoft Metashape professional 1.6.5 software package to produce an orthophoto and a digital surface model (DSM). Image analysis was performed using ArcGIS 10.8,1 software (ESRI, Ltd., Novi Beograd, Serbia). Plant pixels were identified and extracted by a manual thresholds setting, based on DSM, which represents the height of the canopy, and the green and NIR bands often used to differentiate between soil and vegetation pixels. Following initial extraction of vegetation pixels, the normalized difference red edge (NDRE) vegetation spectral index (Potgieter et al. 2017) was calculated using:

Equation (1):

$$
\mathrm{NDRE}=(\mathrm{NIR}-\text { red edge }) /(\mathrm{NIR}+\text { red edge })
$$

NDRE is similar to the common NDVI (normalized difference vegetation index), yet instead of using the red band, it uses the red-edge band. NDRE is considered a better marker of plant conditions when dealing with mature trees, as red-edge light can pass through the leaves far deeper than the red light. Moreover, NDVI often becomes inaccurate (saturated) after plants accumulate their maximum amount of chlorophyll content (Becker et al. 2020).

Avocado leaf pixels were further identified and extracted by a manual threshold setting of NDRE $>0.3$. Using a GIS layer of $1.2 \mathrm{~m}$ circle polygons for each tree, a mean NDRE value in each polygon was calculated using the tool Zonal Statistics from the Spatial Analyst Toolbox in ArcGIS.

\subsection{Productivity}

Fruits were harvested and weighed separately per tree during the 2019 and 2020 seasons. To calculate the fruit number per tree, a random ten-fruit sample from each tree was weighed.

\subsection{Stem Water Potential (SWP)}

Mature leaves were enclosed in aluminum foil lined sealable bags for two hours before measurement. SWP was measured in a Scholander-type pressure chamber (MRC, Israel) according to [38]. In two rootstocks (VC840 and VC152), SWP was measured a day before the initiation of salinity treatment (March 2019), and four more times at 2-week intervals.

\subsection{Susceptibility Rating}

On each index that was tested in this work $(\mathrm{Cl}$ and $\mathrm{Na}$ leaf concentrations, osmolality, visual damage, trunk circumference, $\mathrm{LAI}, \mathrm{CO}_{2}$ assimilation, stomatal conductance, NDRE, trichomes density, and yield), the rootstocks were ranked from 1 to 20 , according to their relative salt sensitivity (20-the most susceptible rootstock, 1 -the most tolerant one). The average indices' score of each rootstock was calculated to obtain the final rating. 


\subsection{Statistical Analysis}

$\mathrm{JMP}^{\circledR}$ 14.0.0 software (SAS Institute Inc., Cary, North Carolina, USA) was used to carry out ANOVA and correlation analysis. The Tukey-Kramer test was used to estimate the differences between the rootstocks at $p \leq 0.05$.

\section{Results}

Leaf concentrations of $\mathrm{Cl}$ and $\mathrm{Na}$ were compared with the toxic thresholds for avocado suggested by the University of California (http:/ / ucavo.ucr.edu/General/LeafAnalysis, accessed on 10 August 2021). $\mathrm{Cl}$ leaf concentration measured in most rootstocks was higher than the upper threshold of $0.25 \%$ (Figure 1A). However, in some rootstocks, this was the case only in 2020. The highest $\mathrm{Cl}$ levels in 2020 were found in Dusa and VC $840(0.76 \%$ and $0.72 \%$, respectively), while the lowest $\mathrm{Cl}$ concentration was measured in VC 152 leaves $(0.21 \%)$. Na leaf concentration was not affected significantly by the rootstocks in 2019 (Figure 1B). However, in 2020 the highest level of leaf Na was found in VC 840 and the lowest in VC 159. No rootstock reached the upper threshold of $0.25 \%$.

After a year of irrigation with water high in salt, salinity damage was observed in some specific rootstocks in the orchard, including leaf necrosis and defoliation (Figure 2). The rootstocks that showed the highest visual salt damage were VC 840, Dusa, VC 207, and VC 802.

The highest leaf osmolality (Figure 3) was measured in VC $840^{\prime}$ s leaves: $728 \mathrm{~mol} \mathrm{~kg}^{-1}$. The lowest osmolality was found in VC 152's leaves: $583 \mathrm{~mol} \mathrm{~kg}^{-1}$.

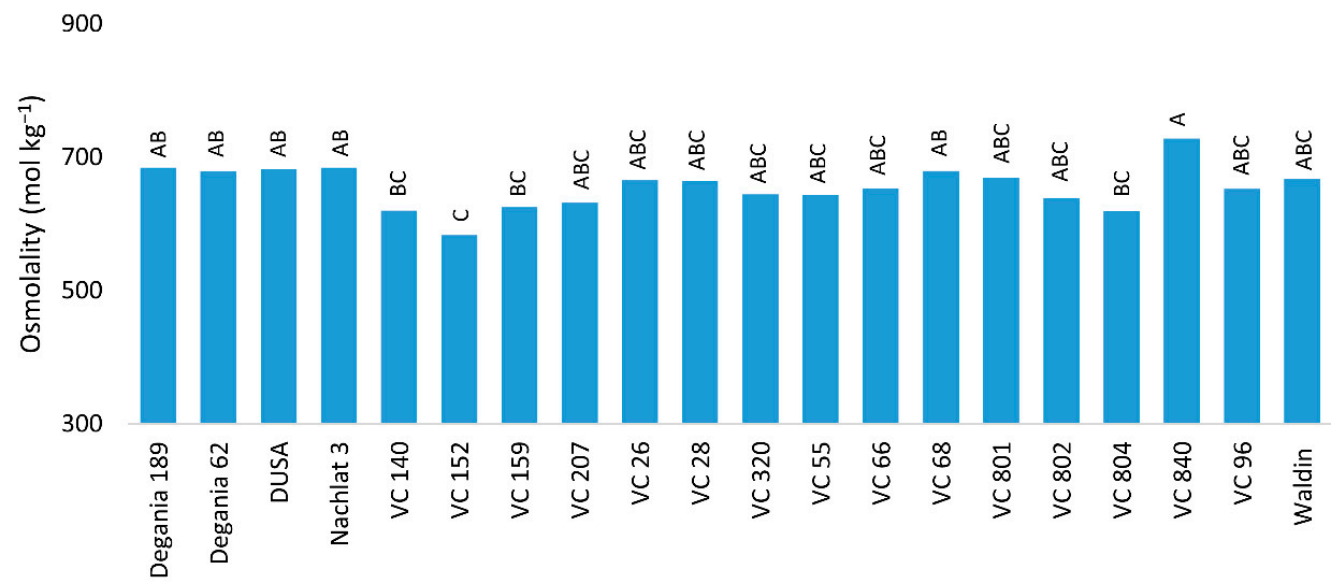

Figure 3. Leaf osmolality of 'Hass' avocado trees grafted onto various rootstocks, after 18 months of salinity exposure. Different letters represent significant $(p \leq 0.05)$ differences between rootstocks. SD values are presented in Table S1.

The average biannual increase in trunk circumference for all rootstocks was nearly $17 \%$ (Figure $4 \mathrm{~A}$ ). VC 152 grew the most, with an increase of $26 \%$, while VC 840 's increase was the lowest-only $11 \%$-and Dusa increased $14 \%$. The highest LAI was found in VC 320, Degania 62, and VC 804 (Figure 4B). The lowest LAI was measured in VC 840 and Nachlat 3.

Photosynthesis rates were affected by the rootstock (Figure 5). The highest stomatal conductance (gs) was measured in leaves of VC 152 (Figure 5A). The lowest gs values were measured in Nachlat 3, VC 802, and VC 96 were nearly half the value of highest. Similar results were found regarding $\mathrm{CO}_{2}$ assimilation (Figure 5B). 

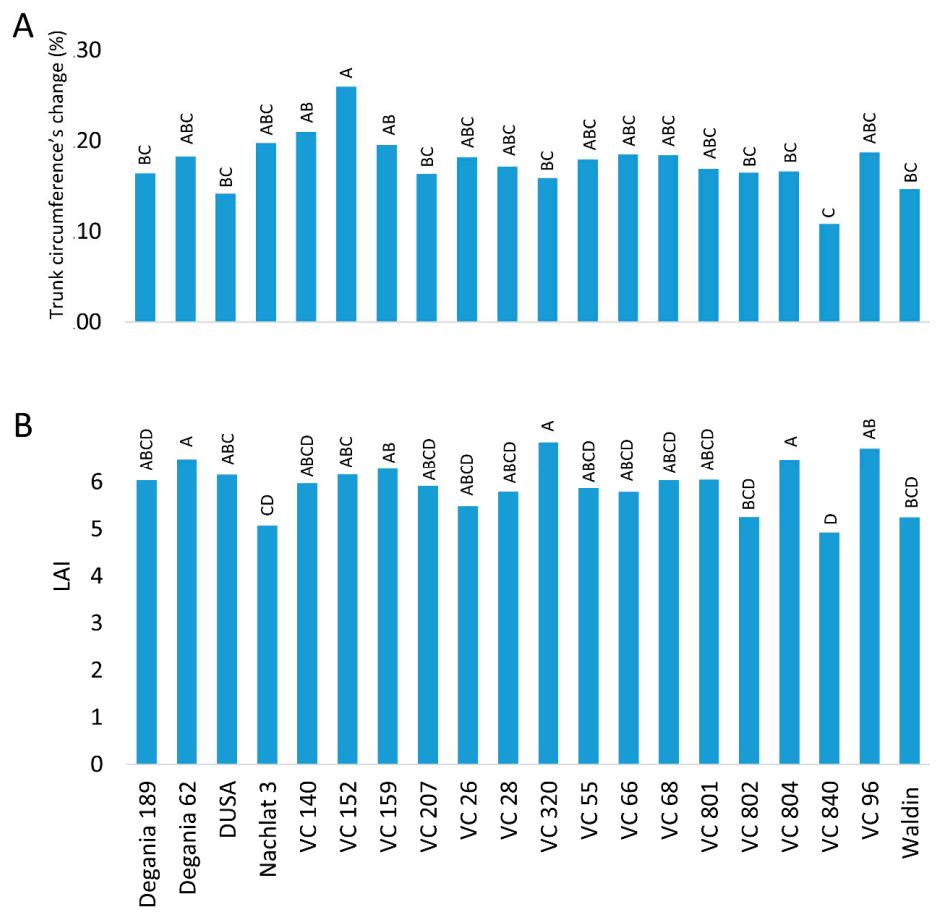

Figure 4. Vegetation indices of 'Hass' avocado trees grafted onto various rootstocks. (A): the relative change in trunk circumference from 2018 to 2020 (under salinity conditions). (B): leaf area index (LAI) measured in August 2020. Different letters represent significant $(p \leq 0.05)$ differences between rootstocks. SD values are presented in Table S1.
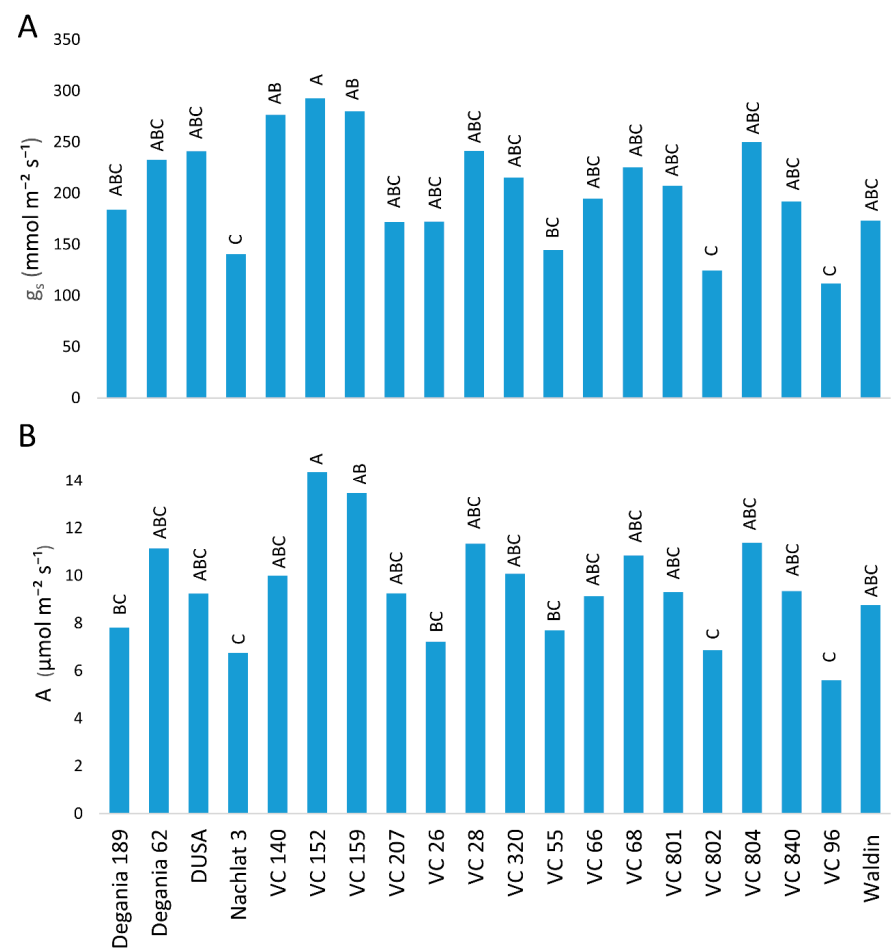

Figure 5. Stomatal conductance (A) and $\mathrm{CO}_{2}$ assimilation (B) of 'Hass' avocado trees grafted onto various rootstocks, after 18 months of salinity exposure. Different letters represent significant $(p \leq 0.05)$ differences between rootstocks. SD values are presented in Table S1. 
In the NDRE mosaic (Figure 6A), red represents bare soil, yellow to pale green indicates stressed plants, and dark green to blue shows vigorous canopy (Figure 6A) (see https: $/ /$ micasense.com/what-is-ndre, accessed on 10 August 2021). We found the highest NDRE values in rootstocks VC 802, Degania 62, and VC 159, and the lowest in VC 840 and Dusa (Figure 6B).

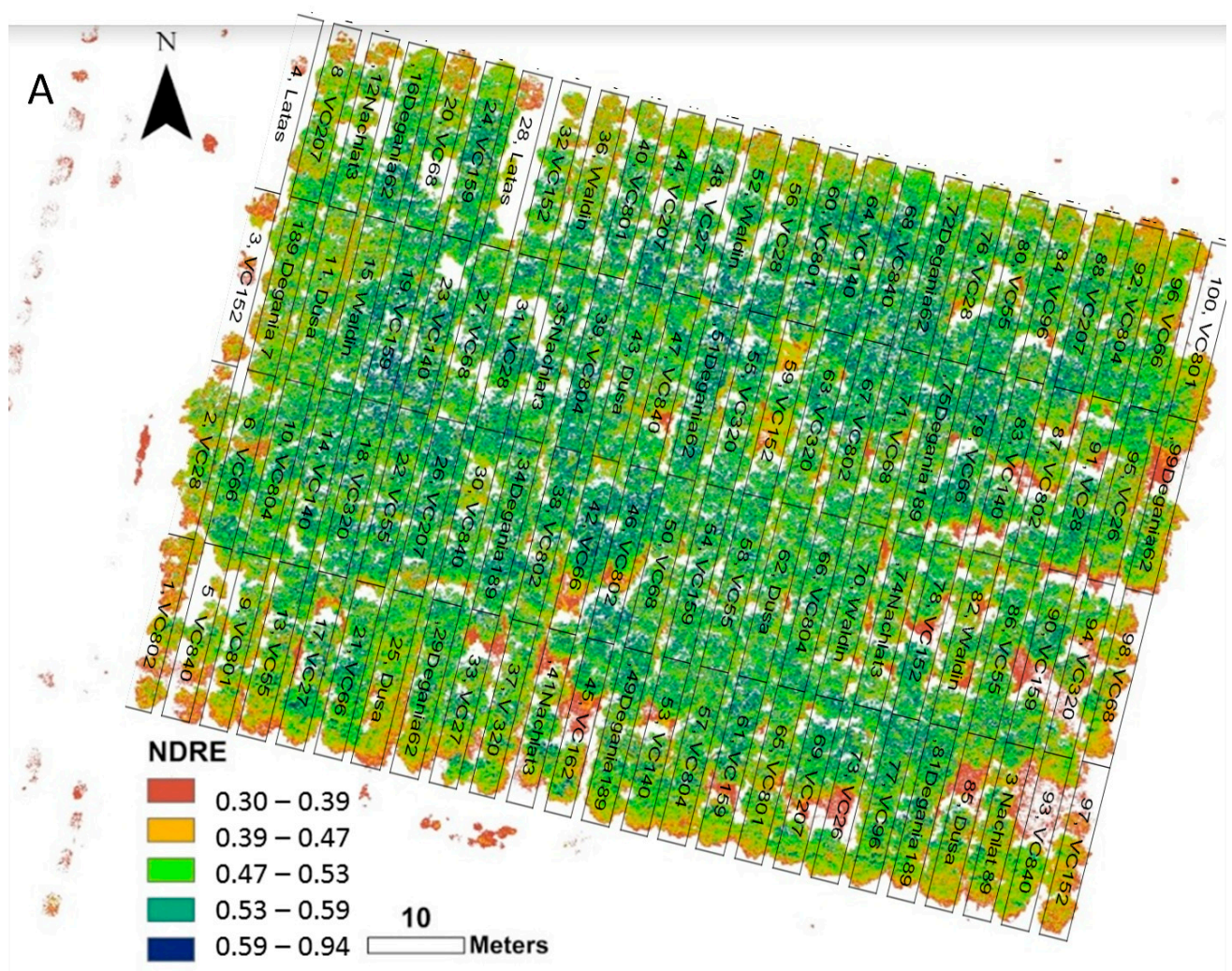

B

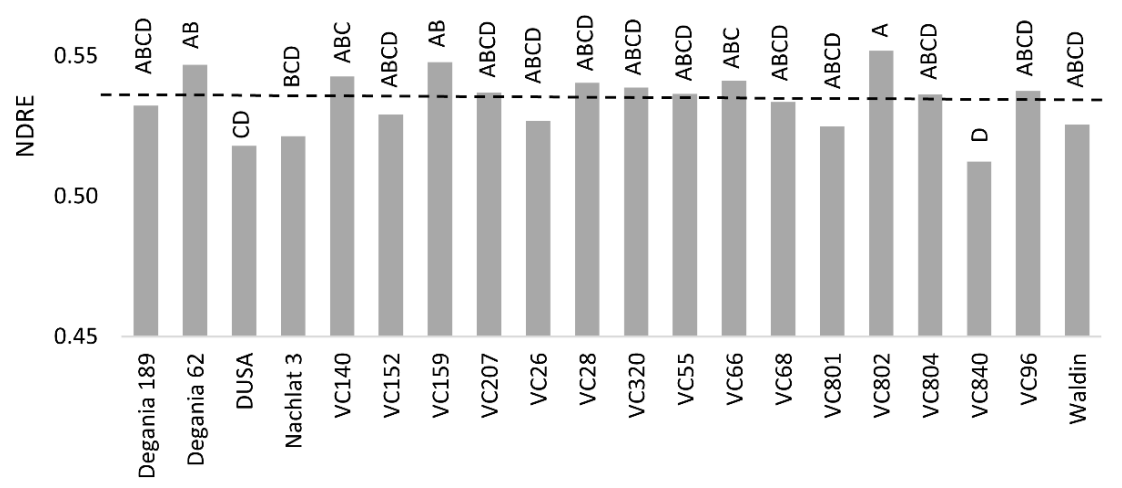

Figure 6. Normalized difference red edge (NDRE) index of 'Hass' avocado trees grafted onto various rootstocks, after 18 months of salinity exposure. (A): NDRE mosaic visualization over the orchard map. (B): average NDRE values according to rootstock. Different letters represent significant $(p \leq 0.05)$ differences between rootstocks. The dashed line represents the 0.53 NDRE value, above which plants are considered non-stressed (see https://micasense.com/what-is-ndre, accessed on 10 August 2021). SD values are presented in Table S1. 
Trichome density was significantly different between 'Hass' leaves that were grafted on different rootstocks (Figure 7). The highest quantity of trichomes per $300 \mu \mathrm{m}^{2}$ was measured in VC 840 leaves (15.5) and the lowest in VC 804 (5.25).

A
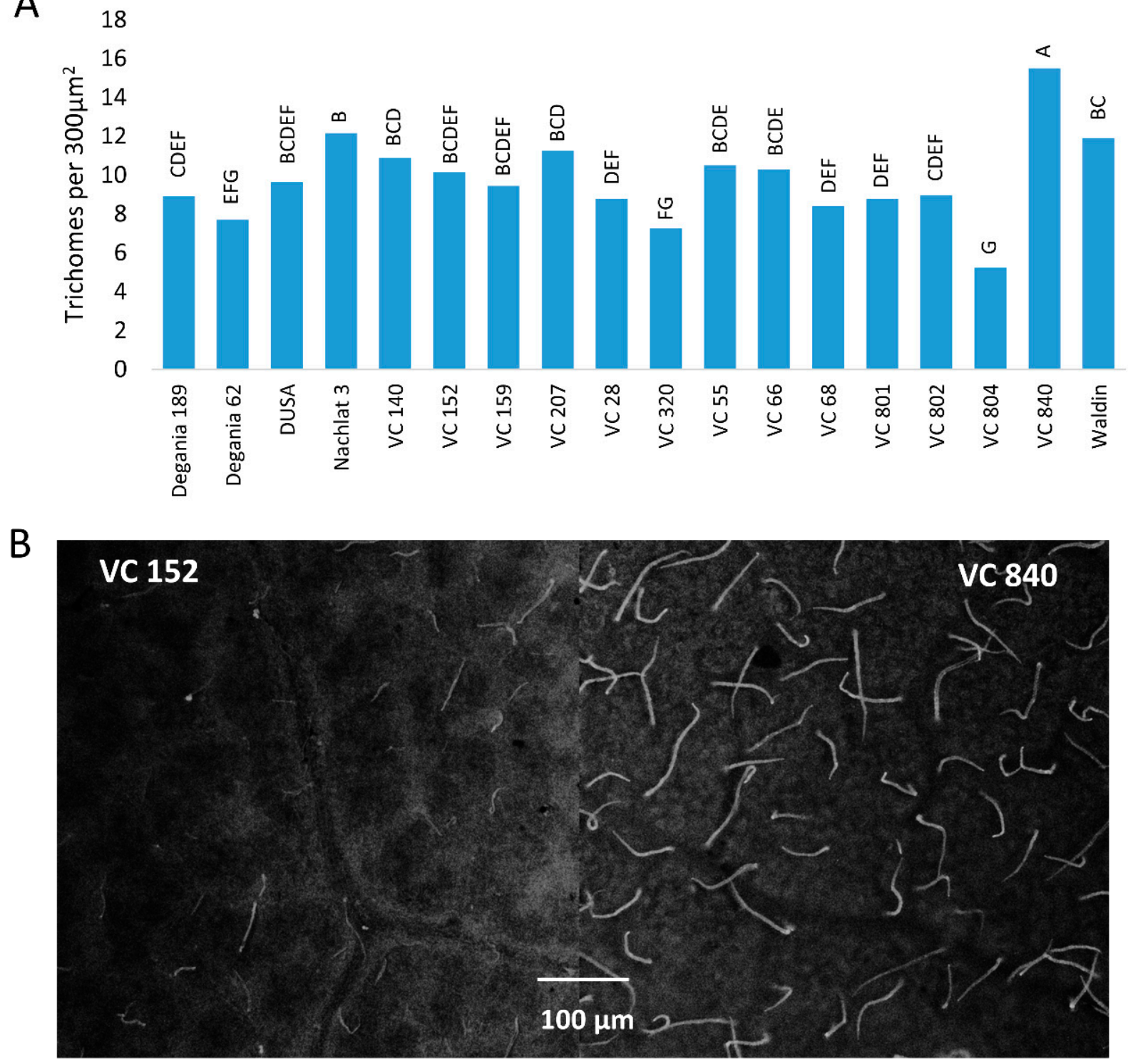

Figure 7. Trichome density on the abaxial side of 'Hass' avocado leaves. (A): the effect of rootstocks on trichome density after 18 months of salinity exposure. (B): live avocado leaves of VC 152 and VC 840 under a stereoscope. Different letters represent significant $(p \leq 0.05)$ differences between rootstocks. SD values are presented in Table S1.

As avocado trees exhibit alternate bearing cycles, we chose to present the average biannual yield of 2019-2020 (under salinity conditions). We found significant differences between the yields of the rootstocks (Figure 8). The highest yields were those of VC 68 and Degania 62, and the lowest were recorded in VC 26, VC 802, VC 801, and Waldin. 


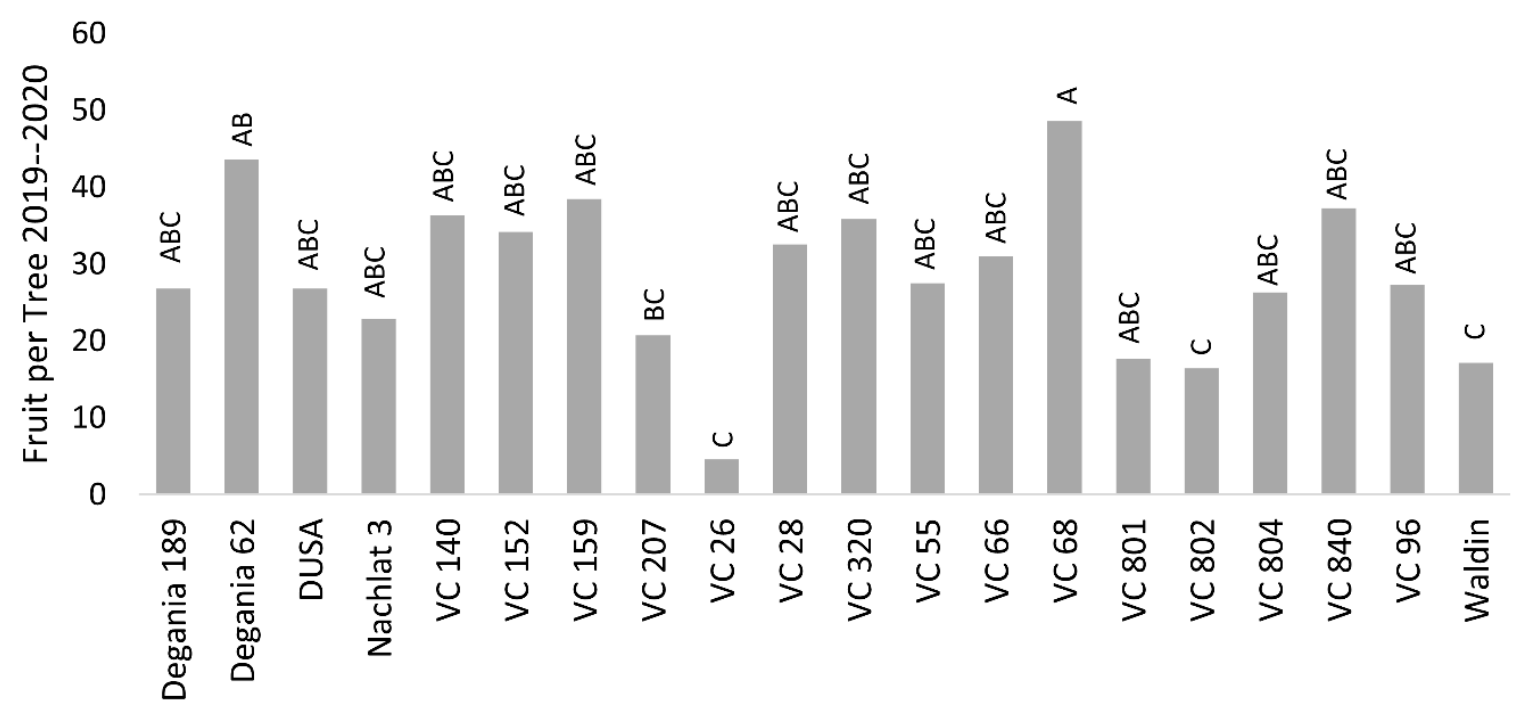

Figure 8. Biannual yield (average number of fruit per tree) of 'Hass' avocado trees grafted onto various rootstocks, under salinity exposure. Different letters represent significant $(p \leq 0.05)$ differences between rootstocks. SD values are presented in Table S1.

Correlation analyses between the different indices of all rootstocks revealed a significant affinity between the canopy volume and LAI, PAR, yield and the relative change in trunk circumference (Table 2). The photosynthesis indices (gs, A, and E) were highly correlated with each other. The transpiration was also correlated with LAI and PAR. Cl leaf concentration was significantly correlated with LAI, leaf osmolality, trichomes number and the change in trunk circumference.

Table 2. Correlation probability between the developmental and physiological indices that were tested among the rootstocks. $\mathrm{g}_{\mathrm{s}}$ : stomatal conductance. A: $\mathrm{CO}_{2}$ assimilation. E: transpiration. LAI: leaf area index. PAR: photosynthetic active radiation. Osmol: leaf osmolality. FPT: fruit per tree. Trich: trichomes. TC: trunk circumference. Bold font represents significant $(p \leq 0.05)$ correlation between indices.

\begin{tabular}{|c|c|c|c|c|c|c|c|c|c|c|}
\hline & $\begin{array}{c}\text { Canopy } \\
\text { Vol. }\end{array}$ & $\mathrm{g}_{\mathrm{s}}$ & $\mathbf{A}$ & $\mathbf{E}$ & LAI & PAR & Osmol. & $\begin{array}{l}\text { Yield 19-20 } \\
\text { (FPT) }\end{array}$ & Trich & $\mathrm{Cl}(\%)$ \\
\hline$g_{s}$ & 0.7717 & & & & & & & & & \\
\hline $\mathrm{A}$ & 0.2217 & $<0.0001$ & & & & & & & & \\
\hline E & 0.1758 & $<0.0001$ & $<0.0001$ & & & & & & & \\
\hline LAI & $<0.0001$ & 0.0522 & 0.2099 & 0.0043 & & & & & & \\
\hline PAR & $<0.0001$ & 0.9557 & 0.8939 & 0.0452 & $<0.0001$ & & & & & \\
\hline Osmolality & 0.3125 & 0.7451 & 0.8919 & 0.5665 & 0.8503 & 0.3706 & & & & \\
\hline Yield 19-20 (FPT) & 0.0163 & 0.2960 & 0.4726 & 0.5119 & 0.0012 & 0.7984 & 0.8084 & & & \\
\hline Trichomes & 0.7245 & 0.2420 & 0.9788 & 0.0693 & 0.3993 & 0.0338 & 0.2112 & 0.7814 & & \\
\hline $\mathrm{Cl}(\%)$ & 0.9285 & 0.4523 & 0.4686 & 0.7877 & 0.0108 & 0.3409 & 0.0131 & 0.0657 & 0.0002 & \\
\hline Change in TC $(\%)$ & 0.0050 & 0.3234 & 0.0649 & 0.2748 & 0.3633 & 0.6928 & 0.0048 & 0.3140 & 0.8209 & 0.0304 \\
\hline
\end{tabular}

The two rootstocks that exhibited the highest and lowest leaf $\mathrm{Cl}-\mathrm{VC} 840$ and VC 152, respectively-were chosen for an in-depth investigation of their response to salt in terms of water stress. These rootstocks had a significant difference in leaf $\mathrm{Cl}$ and SWP even before salinity exposure, but the response to stress, as expressed in SWP, was faster and stronger in VC 840, compared with VC 152 (Figure 9). 


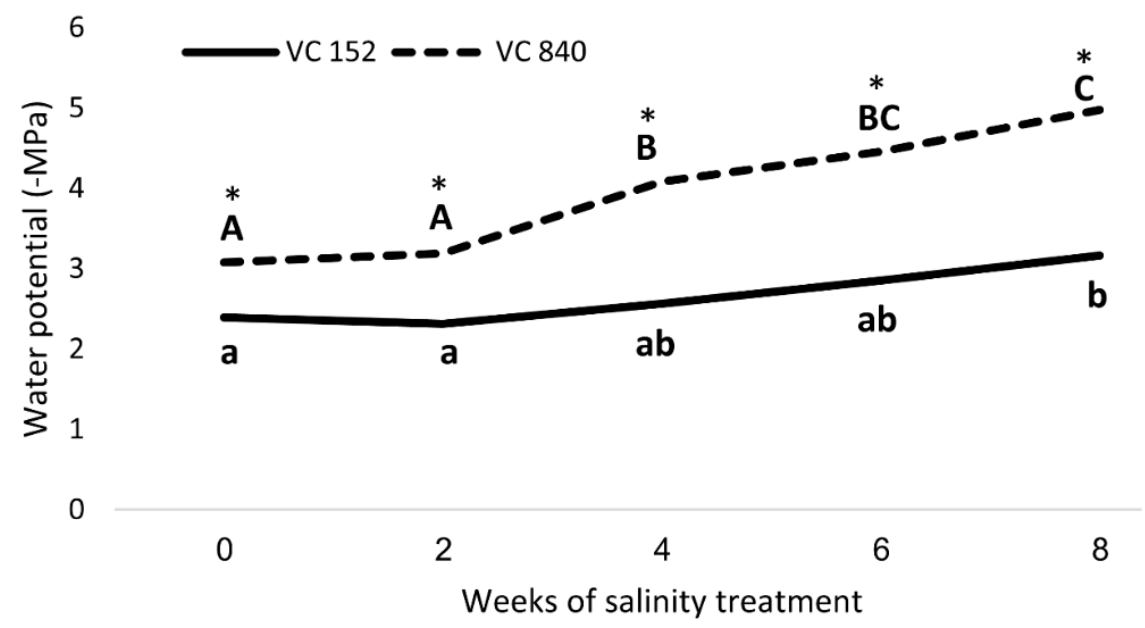

Figure 9. Stem water potential in 'Hass' avocado trees grafted onto either VC152 or VC840 rootstocks along eight weeks of salinity treatment. ${ }^{*}$ represents a significant difference $(p \leq 0.05)$ between the rootstocks. Different letters represent significant differences between measurement dates in a specific rootstock.

For each salt-related index tested in this work, rootstocks were scored progressively from 1 to 20 , according to their measured performance; 1 -the least salt sensitive rootstock, and 20-the most sensitive. We calculated the overall score of the rootstocks (Table 3) and the results demonstrate the divergent susceptibility of avocado rootstocks to salt. The most susceptible rootstocks were VC840, Dusa, and VC802. The least susceptible were VC159, VC140, and VC152.

Table 3. Salt susceptibility rating of avocado rootstocks under EC 1.4-1.5 dS/m

\begin{tabular}{|c|c|c|}
\hline Rootstock & Final Score & \\
\hline VC 840 & 16.8 & $\frac{0}{2}$ \\
\hline Dusa & 15.2 & 륨 \\
\hline VC 802 & 14.8 & : \\
\hline Degania 189 & 12.8 & $\stackrel{n}{\omega}$ \\
\hline VC 801 & 12.7 & $\frac{\infty}{\infty}$ \\
\hline VC 207 & 12.6 & $\sum^{0}$ \\
\hline Waldin & 12.5 & $\frac{4}{\uparrow}$ \\
\hline Nachlat 3 & 12.2 & \\
\hline VC 26 & 11.1 & \\
\hline VC 55 & 11.1 & \\
\hline VC 66 & 10.1 & \\
\hline VC 96 & 9.4 & \\
\hline VC 28 & 9.4 & \\
\hline Degania 62 & 9.3 & $\downarrow$ \\
\hline VC 68 & 8.5 & 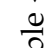 \\
\hline VC 320 & 7.1 & 贾 \\
\hline VC 804 & 6.4 & 它 \\
\hline VC 152 & 6.0 & $\sum_{\infty}^{\infty}$ \\
\hline VC 140 & 5.8 & + \\
\hline VC 159 & 4.8 & త్ర \\
\hline
\end{tabular}

\section{Discussion and Conclusions}

The fact that leaf $\mathrm{Cl}$ concentrations are influenced by rootstocks has been reported for many crops, among them grapevine [39], pomegranate [40], citrus [41], and avocado [18]. This phenomenon is likely to stem from divergent levels of root $\mathrm{Cl}$ absorption and exclusion, as well as transport mechanisms [42-44]. In our experiment, the rootstocks that exhibited 
the highest leaf $\mathrm{Cl}$ concentration (VC 840 and Dusa, Figure 1) were both of a Mexican genetic background, which is characterized by this trait $[17,45,46]$. The combination of 'Hass' scion with a Mexican rootstock was found to be extremely salt-sensitive, with significant damages when the EC is higher than $0.6 \mathrm{dS} / \mathrm{m}$ [47].

Dusa, the second most susceptible rootstock in our orchard, was reported as a topproducer under salinity conditions similar to ours $(E C=1.5 \mathrm{dS} / \mathrm{m})$ in a previous study, which compared 13 avocado rootstocks in California [48]. However, this result changed after the first year of their experiment. Considering the fact that most of the trees in [48] did not survive the experiment, we suggest that the rootstocks that were included in the experiment were relatively salt-sensitive, while our rootstock collection comprised a wide range of responses to salinity, including various levels of tolerance, as reported in $[12,16,49,50]$. However, in our study, Dusa leaves accumulated more $\mathrm{Cl}$ ions in the second year of the experiment, compared with the first one (Figure 1), which suggests a gradual response to salt exposure, similarly to [48].

Visual salt damage was most severe in the rootstocks with a Mexican background (VC 840, Dusa, and VC 207), but also in a West Indian rootstock-VC 802 (Figure 2). Leaf necrosis and defoliation are known manifestations of the toxic effect of $\mathrm{Cl}$, as was reported, among others, for citrus [51], and poplar [52]. A common indication of ion accumulation in the leaves is the osmolality [53], which was also highest in VC 840 (Figure 3). Leaf osmolality increased under $\mathrm{NaCl}$ stress in grapevine [54] and almonds [55], where $\mathrm{Cl}$ ions were found to account for most of it.

In accordance with the known limitations of vegetative growth due to salinity [56], we observed relative differences in LAI and trunk circumference between the rootstocks in the orchard. VC 840 was the most effected rootstock for both variables (Figure 4). VC 152 , which was ranked highest in trunk growth, accumulated the least amount of $\mathrm{Cl}$ in the leaves and exhibited the lowest leaf osmolality. These results strengthen the effect of stress on plant vigor, and the rootstock's major influence over both salt-susceptibility and vegetative growth.

Salt stress may limit the photosynthetic capacity of crop plants and harm their growth and development [57]. High leaf concentrations of $\mathrm{Na}$ are known to reduce stomatal conductance [58]. High leaf concentrations of $\mathrm{Cl}$ are known to damage photosynthesis via chlorophyll degradation [59]. Chlorophyll degradation and low stomatal conductance reduce $\mathrm{CO}_{2}$ assimilation [60]. This is in line with our results, where VC 152, which had the lowest salt leaf concentrations, showed the highest photosynthesis rates (Figure 5). A recent research focused on the most salt-tolerant rootstocks from [48]-R0.05, Dusa, and PP40 - and investigated their development, photosynthesis rates, and physiological traits [61]. Similar to our results, they found that salinity decreased photosynthesis and impaired plant performance.

Spectral reflectance was previously used to measure salinity damage in sunflowers [62] and several landscape species [63]. In avocado orchards, spectral tools were found to be accurate in evaluating the vegetative status [64]. NDRE was chosen for our experiment due to its high sensitivity compared with NDVI [65]. NDRE values supported our other findings of VC 840 and Dusa as the most salt-susceptible rootstocks in the orchard (Figure 6).

The highest trichome density was found in the leaves of VC 840 (Figure 7) and the lowest in VC 804, which exhibited high LAI (Figure 4) and the lowest leaf $\mathrm{Cl}$ in 2019 (Figure 1). It is noteworthy that LAI and trichome density were negatively associated in other rootstocks as well, although we did not find a significant correlation between these indices (Table 2). This finding is novel for avocado. As trichome density was found to increase under salinity in several other plants [66-68], we suggest our original finding as an additional indicator for salt susceptibility in avocado rootstocks. The physiological or developmental mechanism that correlates trichomes with salinity exposure is a subject for additional research.

Salt stress is known to negatively affect plant productivity [57]. Reproductive development can be quantified in several phenological stages-flowering, fruit set, fruit 
growth, and the resulted yield. In this work, we chose the final number of fruit per tree (FTP) as the objective, but did not find strong associations between the stress indications and the yields (Table 2). The highest FTP was found for VC 68 and Degania 62, and the lowest were recorded for VC 26, VC 802, VC 801, and Waldin (Figure 8). However, VC 802 had a relatively high leaf $\mathrm{Cl}$ concentration and low photosynthesis rates, and Degania 62 exhibited high LAI and low trichome density. We assume that in an alternate-bearing tree like avocado, the salinity effect over the yield will be strengthened as the salt treatment continues for years.

After considering all the results, we focused on two rootstocks with opposing response to salt-VC 840 (most susceptible) and VC 152 (least susceptible). Measurements of SWP revealed a significant difference between these rootstocks (Figure 9): VC 840's SWP was more negative even before the initiation of salt treatment, and the trees exhibited stress indication weeks before the VC 152 trees did. VC 840 stress reaction was more intensive than that of VC 152, as the relative change in SWP due to saline irrigation was stronger in VC 840 (Figure 9). This result, which suggests that differences in salt sensitivity can be predicted even before salinity exposure, requires further validation and extension.

To conclude, salinity is one of the most limiting factors in avocado cultivation, and finding a tolerant rootstock is a challenge for the global avocado industry. There are hundreds of known avocado rootstocks from which commercial nurseries choose their grafting material. Our work was based on ongoing Israeli research programs, representing a wide range of rootstocks with divergent characteristics and relatively high tolerance to biotic and abiotic stresses. The presented work contributes to the global avocado database by comparing the physiological response of 20 commercial rootstocks to salt exposure. In addition to our specific results, we believe that the methodologies that were used in the study can provide an applicative and desirable tool for avocado growers and researchers in areas concerned with soil salinity, particularly when induced through low-quality irrigation water.

Supplementary Materials: The following are available online at https:/ /www.mdpi.com/article/10 .3390/plants10081672/s1, Figure S1: The orchard map, Table S1: SD values for figures 1, 3, 4, 5, 6, 7, and 8.

Author Contributions: Conceptualization, S.L. and A.D.; methodology, S.L., Y.C., U.Y., and A.D; data curation, S.L. and E.G.; analysis and visualization, S.L.; writing-original draft, S.L.; writing-review and editing, Y.C., E.G., U.Y., A.B.-G., and A.D. All authors have read and agreed to the published version of the manuscript.

Funding: This research did not receive any specific grant from funding agencies in the public, commercial, or not-for-profit sectors.

Acknowledgments: We thank Yulia Subbotin, Talal Hawashla, Yonatan Ron, Inna Faingold, Guy Liddor, and Ohaliav Keisar for technical support in the field and laboratory.

Conflicts of Interest: The authors declare no conflict of interest.

\section{References}

1. Whiting, M. Precision orchard systems. In Automation in Tree Fruit Production: Principles and Practice; CABI: Wallingford, UK, 2018; pp. 75-93.

2. Rincon-Patino, J.; Lasso, E.; Corrales, J.C. Estimating avocado sales using machine learning algorithms and weather data. Sustainability 2018, 10, 3498. [CrossRef]

3. Chartzoulakis, K.; Patakas, A.; Kofidis, G.; Bosabalidis, A.; Nastou, A. Water stress affects leaf anatomy, gas exchange, water relations and growth of two avocado cultivars. Sci. Hortic. 2002, 95, 39-50. [CrossRef]

4. Carr, M. The water relations and irrigation requirements of avocado (Persea americana Mill.): A review. Exp. Agric. 2013, 49, 256-278. [CrossRef]

5. Vishwakarma, K.; Upadhyay, N.; Kumar, N.; Yadav, G.; Singh, J.; Mishra, R.K.; Kumar, V.; Verma, R.; Upadhyay, R.G.; Pandey, M.; et al. Abscisic acid signaling and abiotic stress tolerance in plants: A review on current knowledge and future prospects. Front. Plant Sci. 2017, 8, 161. [CrossRef] 
6. Nemera, D.B.; Bar-Tal, A.; Levy, G.J.; Lukyanov, V.; Tarchitzky, J.; Paudel, I.; Cohen, S. Mitigating negative effects of long-term treated wastewater application via soil and irrigation manipulations: Sap flow and water relations of avocado trees (Persea americana Mill.). Agric. Water Manag. 2020, 237, 106178. [CrossRef]

7. Vargas-Canales, J.M.; Carbajal-Flores, G.; Bustamante-Lara, T.I.; Camacho-Vera, J.H.; Fresnedo-Ramírez, J.; Palacios-Rangel, M.I.; Rodríguez-Haros, B. Impact of the Market on the Specialization and Competitiveness of Avocado Production in Mexico. Int. J. Fruit Sci. 2020, 20, S1942-S1958. [CrossRef]

8. Smith, L.; Dann, E.; Pegg, K.; Whiley, A.; Giblin, F.; Doogan, V.; Kopittke, R. Field assessment of avocado rootstock selections for resistance to Phytophthora root rot. Australas. Plant Pathol. 2011, 40, 39-47. [CrossRef]

9. Auger, J.; Palma, F.; Pérez, I.; Esterio, M. First report of Neofusicoccum australe (Botryosphaeria australis), as a branch dieback pathogen of avocado trees in Chile. Plant Dis. 2013, 97, 842. [CrossRef]

10. Haberman, A.; Lazare, S.; Hazanovsky, M.; Lebiush, S.; Zipori, I.; Busatn, A.; Simenski, E.; Dag, A. Management of Verticillium Wilt of Avocado Using Tolerant Rootstocks. Plants 2020, 9, 531. [CrossRef] [PubMed]

11. Martínez-Ferri, E.; Moreno-Ortega, G.; van den Berg, N.; Pliego, C. Mild water stress-induced priming enhance tolerance to Rosellinia necatrix in susceptible avocado rootstocks. BMC Plant Biol. 2019, 19, 458. [CrossRef]

12. Ben-Ya'acov, A.; Michelson, E.; Zilberstaine, M.; Barkan, Z.; Sela, I. Selection of clonal avocado rootstocks in Israel for high productivity under different soil conditions. In Proceedings of the 2nd World Avocado Congress, Orange, CA, USA, $21-26$ April 1991.

13. Castro, V.; Iturrieta, E.; Fassio, O. Rootstock effect on the tolerance of avocado plants cv. Hass to NaCl stress. Chil. J. Agric. Res. 2009, 69, 316-324. [CrossRef]

14. Läuchli, A.; Grattan, S. Plant growth and development under salinity stress. In Advances in Molecular Breeding toward Drought and Salt Tolerant Crops; Springer: Dordrecht, The Netherlands, 2007; pp. 1-32.

15. Bernstein, N.; Meiri, A.; Zilberstaine, M. Root growth of avocado is more sensitive to salinity than shoot growth. J. Am. Soc. Hortic. Sci. 2004, 129, 188-192. [CrossRef]

16. Ben-Ya'acov, A.; Michelson, E. Avocado rootstocks. Hortic. Rev. 1995, 17, 381-429.

17. Lazare, S.; Haberman, A.; Yermiyahu, U.; Erel, R.; Simenski, E.; Dag, A. Avocado rootstock influences scion leaf mineral content. Arch. Agron. Soil Sci. 2020, 66, 1399-1409. [CrossRef]

18. Mickelbart, M.V.; Arpaia, M.L. Rootstock Influences Changes in Ion Concentrations, Growth, and Photosynthesis of 'Hass' Avocado Trees in Response to Salinity. J. Am. Soc. Hortic. Sci. 2002, 127, 649-655. [CrossRef]

19. Musyimi, D.; Netondo, G.; Ouma, G. Effects of salinity on growth and photosynthesis of avocado seedlings. Int. J. Bot. 2007, 3, 78-84. [CrossRef]

20. Alvarez-Acosta, C.; Marrero-Dominguez, A.; Gallo-Llobet, L.; Gonzalez-Rodriguez, A.M. Physiological response of selected avocados (Persea americana) subjected to $\mathrm{NaCl}$ and $\mathrm{NaHCO} 3$ stress. Sci. Hortic. 2018, 237, 81-88. [CrossRef]

21. Mickelbart, M.V.; Melser, S.; Lu Arpaia, M. Salinity-induced changes in ion concentrations of 'Hass' avocado trees on three rootstocks. J. Plant Nutr. 2007, 30, 105-122. [CrossRef]

22. Liang, W.; Ma, X.; Wan, P.; Liu, L. Plant salt-tolerance mechanism: A review. Biochem. Biophys. Res. Commun. 2018, 495, 286-291. [CrossRef]

23. Arif, Y.; Singh, P.; Siddiqui, H.; Bajguz, A.; Hayat, S. Salinity induced physiological and biochemical changes in plants: An omic approach towards salt stress tolerance. Plant Physiol. Biochem. 2020, 156, 64-77. [CrossRef]

24. Corell, M.; Martín-Palomo, M.; Girón, I.; Andreu, L.; Galindo, A.; Centeno, A.; Pérez-López, D.; Moriana, A. Stem water potential-based regulated deficit irrigation scheduling for olive table trees. Agric. Water Manag. 2020, 242, 106418. [CrossRef]

25. Aston, M.; Lawlor, D.W. The relationship between transpiration, root water uptake, and leaf water potential. J. Exp. Bot. 1979, 30, 169-181. [CrossRef]

26. Álvarez, S.; Sánchez-Blanco, M. Long-term effect of salinity on plant quality, water relations, photosynthetic parameters and ion distribution in Callistemon citrinus. Plant Biol. 2014, 16, 757-764. [CrossRef]

27. Shalhevet, J.; Maas, E.; Hoffman, G.; Ogata, G. Salinity and the hydraulic conductance of roots. Physiol. Plant. 1976, 38, $224-232$. [CrossRef]

28. Munns, R.; Passioura, J.B.; Colmer, T.D.; Byrt, C.S. Osmotic adjustment and energy limitations to plant growth in saline soil. New Phytol. 2020, 225, 1091-1096. [CrossRef] [PubMed]

29. Blum, A. Osmotic adjustment is a prime drought stress adaptive engine in support of plant production. Plant Cell Environ. 2017, 40, 4-10. [CrossRef] [PubMed]

30. Caparrotta, S.; Boni, S.; Taiti, C.; Palm, E.; Mancuso, S.; Pandolfi, C. Induction of priming by salt stress in neighboring plants. Environ. Exp. Bot. 2018, 147, 261-270. [CrossRef]

31. Çiçek, N.; Çakirlar, H. The effect of salinity on some physiological parameters in two maize cultivars. Bulg. J. Plant Physiol. 2002, $28,66-74$.

32. Zhou, S.; Duursma, R.A.; Medlyn, B.E.; Kelly, J.W.; Prentice, I.C. How should we model plant responses to drought? An analysis of stomatal and non-stomatal responses to water stress. Agric. For. Meteorol. 2013, 182, 204-214. [CrossRef]

33. Slabu, C.; Zörb, C.; Steffens, D.; Schubert, S. Is salt stress of faba bean (Vicia faba) caused by Na+ or Cl-toxicity? J. Plant Nutr. Soil Sci. 2009, 172, 644-651. [CrossRef] 
34. Shelke, D.; Nikalje, G.; Nikam, T.; Maheshwari, P.; Punita, D.; Rao, K.; Kavi Kishor, P.; Suprasanna, P. Chloride (Cl $\left.{ }^{-}\right)$Uptake, Transport, and Regulation in Plant Salt Tolerance. In Molecular Plant Abiotic Stress: Biology and Biotechnology; Wiley: Hoboken, NJ, USA, 2019; pp. 241-268.

35. Patterson, J.H.; Newbigin, E.; Tester, M.; Bacic, A.; Roessner, U. Metabolic responses to salt stress of barley (Hordeum vulgare L.) cultivars, Sahara and Clipper, which differ in salinity tolerance. J. Exp. Bot. 2009, 60, 4089-4103.

36. Fipps, G. Irrigation water quality standards and salinity management strategies. In Texas Farmer Collection; Texas AgriLife Extension publication, Texas A\&M Univ.: College Station, TX, USA, 2003.

37. Crowley, D. Salinity management in avocado orchards. Calif. Avocado Soc. Yearb. 2008, 91, 83-104.

38. Shackel, K.A. Plant water status as an index of irrigation needs in deciduous fruit trees. HortScience 1995, 30, 905B-905. [CrossRef]

39. Dag, A.; Ben-Gal, A.; Goldberger, S.; Yermiyahu, U.; Zipori, I.; Or, E.; David, I.; Netzer, Y.; Kerem, Z. Sodium and chloride distribution in grapevines as a function of rootstock and irrigation water salinity. Am. J. Enol. Vitic. 2015, 66, 80-84. [CrossRef]

40. Karimi, H.; Hassanpour, N. Effects of salinity, rootstock, and position of sampling on macro nutrient concentration of pomegranate cv. Gabri. J. Plant Nutr. 2017, 40, 2269-2278. [CrossRef]

41. Moya, J.L.; Gómez-Cadenas, A.; Primo-Millo, E.; Talon, M. Chloride absorption in salt-sensitive Carrizo citrange and salt-tolerant Cleopatra mandarin citrus rootstocks is linked to water use. J. Exp. Bot. 2003, 54, 825-833. [CrossRef]

42. Simón-Grao, S.; Nieves, M.; Martínez-Nicolás, J.J.; Cámara-Zapata, J.M.; Alfosea-Simón, M.; García-Sánchez, F. Response of three citrus genotypes used as rootstocks grown under boron excess conditions. Ecotoxicol. Environ. Saf. 2018, 159, 10-19. [CrossRef] [PubMed]

43. Dbara, S.; Melaouhi, A.; Mars, M.; Ben Mimoun, M. Potassium uptake efficiency of two pear cultivars and leaf concentration at deficiency symptoms appears. J. Plant Nutr. 2019, 42, 1660-1667. [CrossRef]

44. Paudel, I.; Bar-Tal, A.; Raveh, E.; Bernstein, N.; Cohen, S. Tolerance of citrus rootstocks to poor water quality is improved by root zone aeration via selective uptake of ions, higher photosynthesis and carbon storage. Sci. Hortic. 2019, 251, 9-19. [CrossRef]

45. Kadman, A.; Ben-Ya'acov, A. Selection of avocado rootstocks for saline conditions. Acta Hort. 1976, 57, 189. [CrossRef]

46. Embleton, T.; Matsumura, M.; Storey, W.; Garber, M. Chlorine and other elements in avocado leaves as influenced by rootstock. Proc. Am. Soc. Hortic. Sci. 1962, 80, 231-236.

47. Oster, J.D.; Stottlmyer, D.; Arpaia, M. Salinity and water effects on 'Hass' avocado yields. J. Am. Soc. Hortic. Sci. 2007, 132, 253-261. [CrossRef]

48. Celis, N.; Suarez, D.L.; Wu, L.; Li, R.; Arpaia, M.L.; Mauk, P. Salt Tolerance and Growth of 13 Avocado Rootstocks Related Best to Chloride Uptake. HortScience 2018, 53, 1737-1745. [CrossRef]

49. Ben-Ya'acov, A. Avocado rootstocks in use in Israel. Calif. Avocado Soc. Yearb. 1976, 59, 66-68.

50. Bernstein, N.; Ioffe, M.; Zilberstaine, M. Salt-stress effects on avocado rootstock growth. I. Establishing criteria for determination of shoot growth sensitivity to the stress. Plant Soil 2001, 233, 1-11. [CrossRef]

51. Hussain, S.; Luro, F.; Costantino, G.; Ollitrault, P.; Morillon, R. Physiological analysis of salt stress behaviour of citrus species and genera: Low chloride accumulation as an indicator of salt tolerance. S. Afr. J. Bot. 2012, 81, 103-112. [CrossRef]

52. Abbruzzese, G.; Beritognolo, I.; Muleo, R.; Piazzai, M.; Sabatti, M.; Mugnozza, G.S.; Kuzminsky, E. Leaf morphological plasticity and stomatal conductance in three Populus alba L. genotypes subjected to salt stress. Environ. Exp. Bot. 2009, 66, 381-388. [CrossRef]

53. Tarakcioglu, C.; Inal, A. Changes induced by salinity, demarcating specific ion ratio $(\mathrm{Na} / \mathrm{Cl})$ and osmolality in ion and proline accumulation, nitrate reductase activity, and growth performance of lettuce. J. Plant Nutr. 2002, 25, 27-41. [CrossRef]

54. Meggio, F.; Prinsi, B.; Negri, A.; Simone Di Lorenzo, G.; Lucchini, G.; Pitacco, A.; Failla, O.; Scienza, A.; Cocucci, M.; Espen, L. Biochemical and physiological responses of two grapevine rootstock genotypes to drought and salt treatments. Aust. J. Grape Wine Res. 2014, 20, 310-323. [CrossRef]

55. Zrig, A.; Mohamed, H.; Tounekti, T.; Ennajeh, M.; Valero, D.; Khemira, H. A comparative study of salt tolerance of three almond rootstocks: Contribution of organic and inorganic solutes to osmotic adjustment. J. Agric. Sci. Technol. 2015, 17, 675-689.

56. Safdar, H.; Amin, A.; Shafiq, Y.; Ali, A.; Yasin, R.; Shoukat, A.; Hussan, M.U.; Sarwar, M.I. A review: Impact of salinity on plant growth. Nat. Sci. 2019, 17, 34-40.

57. Mbarki, S.; Sytar, O.; Cerda, A.; Zivcak, M.; Rastogi, A.; He, X.; Zoghlami, A.; Abdelly, C.; Brestic, M. Strategies to mitigate the salt stress effects on photosynthetic apparatus and productivity of crop plants. In Salinity Responses and Tolerance in Plants; Springer: Cham, Switzerland, 2018; pp. 85-136.

58. Parihar, P.; Singh, S.; Singh, R.; Singh, V.P.; Prasad, S.M. Effect of salinity stress on plants and its tolerance strategies: A review. Environ. Sci. Pollut. Res. 2015, 22, 4056-4075. [CrossRef]

59. Tavakkoli, E.; Rengasamy, P.; McDonald, G.K. High concentrations of $\mathrm{Na}^{+}$and $\mathrm{Cl}^{-}$ions in soil solution have simultaneous detrimental effects on growth of faba bean under salinity stress. J. Exp. Bot. 2010, 61, 4449-4459. [CrossRef]

60. James, R.A.; Rivelli, A.R.; Munns, R.; von Caemmerer, S. Factors affecting $\mathrm{CO}_{2}$ assimilation, leaf injury and growth in salt-stressed durum wheat. Funct. Plant Biol. 2002, 29, 1393-1403. [CrossRef]

61. Acosta-Rangel, A.M.; Li, R.; Celis, N.; Suarez, D.L.; Santiago, L.S.; Arpaia, M.L.; Mauk, P.A. The physiological response of 'Hass' avocado to salinity as influenced by rootstock. Sci. Hortic. 2019, 256, 108629. [CrossRef]

62. Turhan, H.; Genc, L.; Smith, S.; Bostanci, Y.; Turkmen, O. Assessment of the effect of salinity on the early growth stage of the common sunflower (Sanay cultivar) using spectral discrimination techniques. Afr. J. Biotechnol. 2008, 7, 750-756. 
63. Devitt, D.; Morris, R.; Fenstermaker, L. Foliar damage, spectral reflectance, and tissue ion concentrations of trees sprinkle irrigated with waters of similar salinity but different chemical composition. HortScience 2005, 40, 819-826. [CrossRef]

64. Tu, Y.-H.; Johansen, K.; Phinn, S.; Robson, A. Measuring canopy structure and condition using multi-spectral UAS imagery in a horticultural environment. Remote Sens. 2019, 11, 269. [CrossRef]

65. Raeva, P.L.; Šedina, J.; Dlesk, A. Monitoring of crop fields using multispectral and thermal imagery from UAV. Eur. J. Remote Sens. 2019, 52 (Suppl. 1), 192-201. [CrossRef]

66. Zhou, Y.; Tang, N.; Huang, L.; Zhao, Y.; Tang, X.; Wang, K. Effects of Salt Stress on Plant Growth, Antioxidant Capacity, Glandular Trichome Density, and Volatile Exudates of Schizonepeta tenuifolia Briq. Int. J. Mol. Sci. 2018, 19, 252. [CrossRef]

67. Çelik, Ö.; Atak, Ç.; Suludere, Z. Comparative transcriptional profiling of soybean orthologs of Arabidopsis trichome developmental genes under salt stress. Plant Mol. Biol. Report. 2018, 36, 82-93. [CrossRef]

68. Dolatabadian, A.; Sanavy Samm Ghanati, F. Effect of salinity on growth, xylem structure and anatomical characteristics of soybean. Not. Sci. Biol. 2011, 3, 41-45. [CrossRef] 